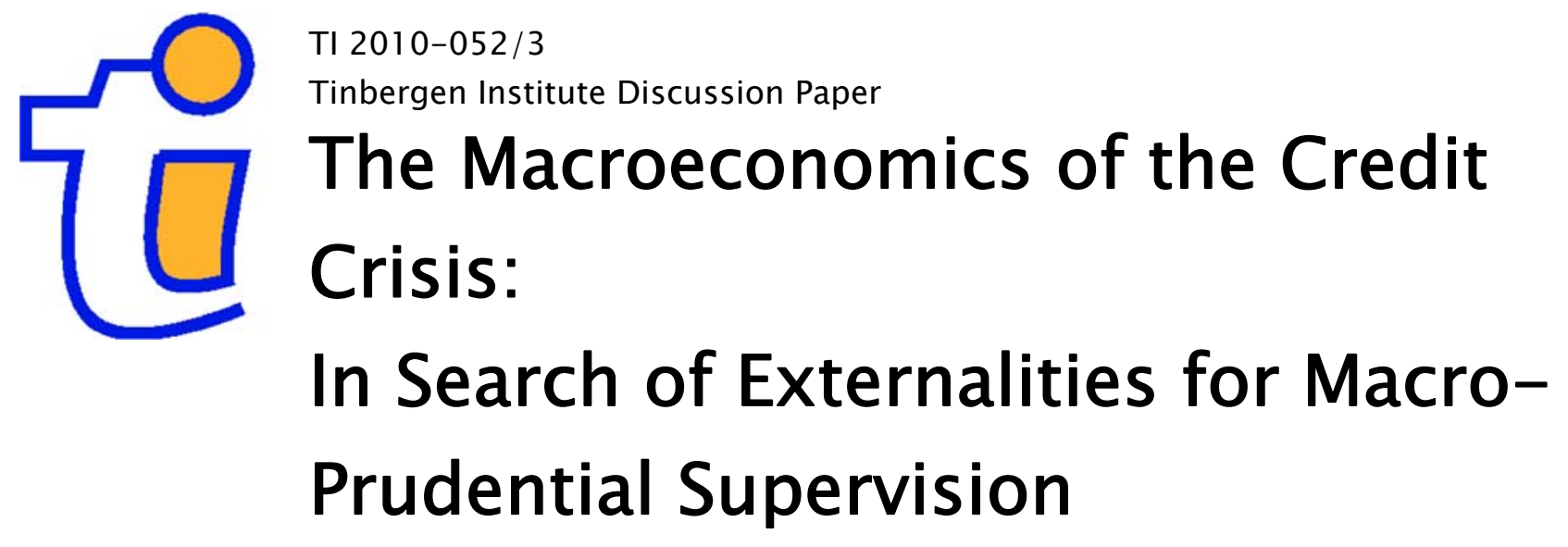

Frank A.G. den Butter

VU University Amsterdam, and Tinbergen Institute. 


\section{Tinbergen Institute}

The Tinbergen Institute is the institute for economic research of the Erasmus Universiteit Rotterdam, Universiteit van Amsterdam, and Vrije Universiteit Amsterdam.

Tinbergen Institute Amsterdam

Roetersstraat 31

1018 WB Amsterdam

The Netherlands

Tel.: +31(0)205513500

Fax: $+31(0) 205513555$

Tinbergen Institute Rotterdam

Burg. Oudlaan 50

3062 PA Rotterdam

The Netherlands

Tel.: + $31(0) 104088900$

Fax: $+31(0) 104089031$

Most TI discussion papers can be downloaded at http://www.tinbergen.nl. 


\title{
The macroeconomics of the credit crisis: in search of externalities for macro-prudential supervision
}

\author{
Frank A.G. den Butter ${ }^{1}$
}

\begin{abstract}
In the analysis of the credit crisis of 2007-2010 a clear distinction should be made between (i) the initial shock; (ii) the propagation and amplification of the initial shock to the systemic crisis of the financial markets; and (iii) the transmission of the credit crisis to the real economic sector causing a major cyclical downturn now known as the great recession. This paper argues that banking supervision failed to anticipate and repair the market failure that caused the huge amplification of the relatively small initial shock. As the repair of market failure is the only sound economic argument for regulation, banking supervisors should now focus on the externalities that caused the amplification of the shock and use that knowledge for adequate macro-prudential supervision in the future. Macro-economic models can be helpful in this search for externalities. The character and timing of future shocks are unpredictable, but contagion in the propagation mechanisms should be mitigated as much as possible.
\end{abstract}

Keywords: credit crisis, externalities, macro-prudential supervision, contagion, fallacy of composition

JEL-codes: E42, E58, G38.

Paper presented at the VIPE Conference "Do rules and regulations bind or build economic development", Wageningen 19 February 2010

Draft 18 March 2010

\footnotetext{
${ }^{1}$ Professor of economics, VU University Amsterdam.
} 


\section{Introduction}

The major cause of the credit crisis of 2007-2010 is insufficient knowledge of banking supervisors of the macro-economic mechanisms that governed the amplification of the relatively small initial shock of a decrease in housing prices in the US, to the financial markets. In other words, it is insufficient knowledge of the externalities that caused the market failure of the financial markets, which resulted in a failure of macro-prudential supervision to prevent the amplification and propagation of the initial shock. It appears that banking supervision, in addition to strong voices and lobby for deregulation in the heydays of the banking profession, was mainly focussing on supervision of individual banks, and was neglecting the macro-economics of the financial sector.

This paper focuses on these externalities which played a crucial role in the amplification of the initial shock. The argument is that the main (or even only) aim of regulation, and hence of banking supervision, is to internalize externalities. So, in order to become a trustworthy regulator again, banking supervisors should analyse which externalities were the cause of the systemic crisis. The problem is that we still do not know about the precise character of the externalities. In this era of easy communication much has been said and written on the causes and consequences of the crisis and on possible solutions. A plethora of opinions is the result. Scientists from other disciplines are eager to blame economists for all what went wrong. In their eyes economics has disproved as serious science because economists were unable to prevent this tragedy, or at least to foresee it. These opinions are often followed by broad reflections on how the economic system in the world or society should be arranged in a completely different manner. But economists themselves have also blurred the debate with a cacophony of opinions.

In the search of externalities which governed the amplification mechanism, this paper limits itself to explaining the causes and remedies of the crisis by using the traditional mainstream economics based on the assumption of rational behaviour. This framework suffices to understand what we do know about the crisis, and more importantly, what we still do not know. From that perspective the following section describes the major suspects of the crisis whereas section 3 discusses a number of alleged misconceptions which in the debate have also been seen as major causes. The propagation mechanisms appear to be so complicated that only a model based analysis can reveal their working. Section 4 surveys models that may be helpful in that respect. A key question in the debate is the predictability of the crisis. Section 5 argues in a more general outlook on this matter that the type and timing of a shock which causes a cyclical downturn is unpredictable. Therefore policy should be concerned with the propagation mechanism. In case of the credit crisis it is essential to make a distinction between (i) the original shock (which was relatively small: a decrease in housing prices in the US lowering the value of subprime mortgages); (ii) propagation of the shock to the financial sector (causing a systemic crisis with a huge amplification of the initial shock); and (iii) propagation of the systemic banking crisis to the real economy: the great recession. Macro-prudential supervision should prevent a systemic crisis by internalizing as much as possible the externalities which contribute to the amplification. Section 6 elaborates this aspect and concludes.

\section{Major causes of the crisis relevant for the search for externalities}


As mentioned above the main aspect to be analyzed in the search for causes of the crisis and the externalities that adequate supervision should internalize, is the fact that a relatively small initial shock was so much amplified. A major observation here is that in the aftermath of the shock the mutual entanglement of the financial sector appeared to be much stronger than that was assumed in quiet times. This is called "contagion", which the World Bank describes as: "Contagion occurs when cross country correlations increase during crisis times relative to correlations during tranquil times". The originate and distribute model of securitization, which was in good times regarded as a useful financial innovation, is now commonly regarded as the prominent cause of the amplification of the shock and of enhancing contagion. Securitization is the bundling of financial assets, including subprime mortgages, in packages, so that they can be sold as liquid assets to financial institutions. This possibility to package and sell, and repackage and sell again has contributed much to the further entanglement in the financial world. It could be compared with AIDS. The securitization can be seen as a form of unsafe sex in a society which has become profoundly promiscuous leading to a global contagion of financial institutions. That's why I sometimes speak of "unsafe" assets. Following this analogy, banking supervision should see to it that the financial world becomes less promiscuous and/or uses better preservatives (condoms)

With rising housing prices in the U.S. the problem with the originate and distribute model remained hidden. The financial innovation of securitization was even seen as a blessing because it seemed to promote risk diversification of financial institutions and it made "clumsy" long term financial assets, including mortgages, liquid and therefore more marketable. The securitization was also considered beneficial because the rising housing prices, which in this context can be seen as a positive shock, enhanced the positive second order effects of securitization for financial institutions. It implied that the lenders could resell their mortgages and with the money thus obtained could provide new mortgages. Here the seed is laid for excessive lending, so that in the long run this financial innovation brought disadvantages rather than benefits. It went really wrong when housing prices fell and the positive shock turned negative. The negative shock was much amplified while the idea was that the risk diversification would have a shock absorbing effect. Apparently there is an asymmetry in the external effects of the securitization: positive to a positive shock and negative to a negative shock. (see eg Gallegati et al, 2008). Thus, this innovation turned from blessing into a curse.

This transfer and shifting of risks in securitization, while benefiting from a relatively high yield, has somewhat the character of a Ponzi game, where a high yield is partly paid by attracting new resources for which a high yield is promised. Activities of hedge funds in a way contain elements of this game, but also the way mortgage lenders, in the originate and distribute model, have benefited from the rising house prices, and hence caused a further rise of those prices, can be characterized as a mild version of a Ponzi game. Of course it is not really the Ponzi game Madoff played by using the deposits of new investors to provide earlier investors the promised high returns. That is outright fraud whereas securitization was regarded an acceptable and in good times even useful financial innovation. 
Anyhow, the way in which the financial innovation of securitization has contributed to the start-up and getting out of control of the crisis, shows that such innovations are not always beneficial for the economy. Compare the example of fishermen who, through an innovation, avail of better nets. Individually, they become more efficient, but collectively it means that the sea will be fished out. However, in case of good regulation which internalizes these externalities - in this case imposing and strict enforcement of fishing quota - the innovation of the better nets would have a positive impact. Productivity increases and the fish becomes less expensive.

This analogy, which of course is not fully comparable to the case of financial innovation, shows how an innovation can reinforce negative externalities when there is no proper regulation of these externalities. Negative externalities in this context mean that the decision of an individual (person or firm) has an adverse impact on others which is not taken properly into account in that individual decision. In contrast, an adequate regulation could even bring about positive externalities. In that case, the innovations are beneficial to others. The fishermen may develop and use more sophisticated nets so that less undersized fish is caught which implies that there is more fish available in the future. The example of the fishermen and fish quota also shows how difficult it can be in practice to regulate properly. A group of independent experts is needed who are to make a credible analysis of the future development of aquatic resources. Even in that case political interests play such a great role in the determination of fishing quotas that the opinion of the experts is often overruled. Eventually, the fishermen themselves suffer from not complying with the quota. This applies equally to banks that only pursue their own interests and ignore the unwarranted boomerang effects of shifting risks away. However, repair of these types of market failure by means of adequate regulation may, just as proper enforcement of fishing quotas, result in a positive contribution to wealth creation by financial innovations. That is why this paper sees the financial innovation of securitization as a major cause of the credit crisis which could have been prevented by an adequate response of regulators.

Second suspect: moral hazard: too much risk and leverage due to prospects for a bailout and too little attention of originator for avoiding default of mortgages

A second suspect of causing the crisis is the moral risk which stimulates irresponsible behaviour in reaction to insurance, or in reaction to the prospects of compensation or help by the government. De Nederlandsche Bank (2009) argues that securitization evokes this problem of moral hazard because the original lender has less incentives to monitor the debtor and order repayment of credit. A similar problem holds in case of a system of deposit-guarantees where depositors are less careful in their assessment of the reliability of the financial institution where they entrust their savings. A prominent example is the insolvency of the Icelandic internet savings bank Icesave. The Nederlandsche Bank (DNB) is less clear on the fact that the prospect of a bailout in case of failure of a financial institution which is "too big to fail" enhances the asymmetry in taking risks. In fact this type of moral hazard can be seen as a major cause of the irresponsible behaviour of banks, which, with a high leverage of borrowed debt took too large risks, or otherwise underestimated their risks. The reward for good luck in those cases accrued to the banks, while bad luck was passed on to society through the bailout. The prevention of these forms of moral hazard is a major concern 
in the design of future measures of supervision of the financial sector (see eg. Bullard et al., 2009).

Although moral hazard provides an explanation for irresponsible behaviour of banks (or of holders of savings) it can very well be avoided. Indeed, the classic situation of moral hazard occurs with insurance where the insured becomes less cautious with taking risks than when he or she would not be insured and thus would suffer a greater loss in case the risk materializes. Insurance companies have learned how to cope with this and avail of many rules and conditions to minimize moral hazard. Therefore, the problem of moral hazard does hinder the shock-dampening effect of risk diversification. In the case of the financial system, however, there is a staggered system of moral hazard. The expectation is that the central bank will intervene and keep affected banks and financial institutions alive. For central banks this is a dilemma as they engage with the rest of the financial world in a sort of "game of chicken". If the central banks (and governments) concede - and in recent times they did - the expectations of the financial institutions is confirmed that in the event of demise they will be saved by a bailout. This is recognized by the central banks but the short-term profits of curbing the crisis are to be weighed against the long-term loss of the prospects for no-bailout. The loss means that the financial institutions become rewarded for their bad behaviour and will take more risks in future. The bailout obviously enhances the moral hazard of financial institutions. In turn, the financial institutions will be less inclined to prevent moral hazard with their customers and thus be less stringent with the requirements of providing risky loans. In that sense the reduced attention to moral hazard that a bailout evokes, has a selfreinforcing element.

Third suspect: fallacy of composition: macro behaviour $\neq$ sum of micro behaviour

As mentioned above a core problem that caused the credit relates to the way the distribution of risks in the financial world takes place. A risk has two dimensions, namely (i) the probability that an event with (negative) financial impact occurs and (ii) the size of the (negative) effect: the damage. The existence of risk means that there is uncertainty. It is essential that the risk is properly assessed. However the claim is incorrect that the failure of the U.S. mortgages increased the risks. That makes no sense, like the claim that when throwing an unbiased dice the probability of getting a 3 increases when one has thrown a 3 .

Insurance companies have a long experience in evaluating risk properly. They will also only increase the insurance premium when a trend increase in the damage amounts (over the insured amount) is detectable. Here, there is even an insurance paradox (see Hinloopen, 2007). It is necessary for the survival of the insurance company that occasionally damage occurs, When there would be no damages, no one would want to insure. Something similar applies in the financial world. When risky venture capital investments were not occasionally confronted with default, there would be no reason to require a high return on such investments. Insurance companies know well how to diversify risks by mutual reinsurance and by combining risks worldwide which are uncorrelated (see Lucas, 2002). This system is (apparently) able to dampen large shocks. Major disasters with much damage have, for the time being, been well absorbed by the system and have not led to a global crisis of insurance. Why is not the 
same true with respect to the risky loans at the subprime mortgage market? Partly this has to do with the other character of the risk in the financial world. The ownership of the risk here is passed to the person or institution that seeks the highest possible return with, from the perspective of the individual investment, the smallest risk. Securitized assets, where risks were bundled together in packages, became popular in that respect. They were easily negotiable and could be kept off-balance by the financial institutions, which provided a cover-up for the risks. Especially hedge funds and investment banks have taken these packets in portfolio and sold them in new combined packages (resecuritization). The result is a very complicated system where it is difficult to obtain overview.

Figure 1. The Penrose triangle symbolizes the fallacy of composition.

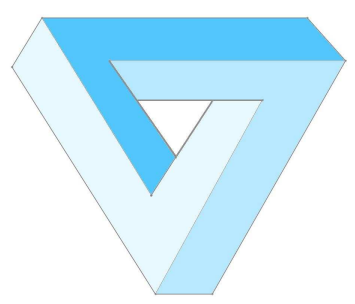

The Penrose triangle is an impossible figure, named after the British mathematician Roger Penrose, who conceived this figure and published it in 1958. The Swedish artist Oscar Reutersvärd already made a drawing of the same triangle in 1934. The triangle consists of three bars that seemingly stand all perpendicular to each other, but together they compose a triangle (see picture). It is an optical illusion. The Dutch graphic artist Maurits Escher often used the Penrose triangle in his work. For the analysis of the credit crisis, the Penrose triangle symbolizes the "fallacy of composition": at the micro level of the vertices everything seems to be correct, but at the macro level the figure is incorrect That is what went wrong with supervision in the credit crisis.

Economic theory gives two fundamental reasons why such a system can go wrong, and why the system may amplify shocks in stead of dampen them. The first is the role of asymmetric information. The buyers of the packets that contain risky assets, have less information about the contents of packets than the sellers (originators). Here market activities are governed by "bounded rationality" when the benefits of additional information do not outweigh the cost of obtaining such additional information. This information asymmetry can be overcome by a mutual trust between traders who buy and sell these complex financial products. If by some reason this trust is violated, the mutual trust no longer serves as a substitute for information about the nature of the financial products. The market collapses and the system breaks down. This is the mechanism which is formalized in a number of model-based explanations of the credit crisis (see section 4). It explains how the economy can move from an equilibrium of mutual trust to an equilibrium of mutual distrust.

The above arguments give rise to consider the "fallacy of composition" as a fundamental cause of the credit crisis (see Figure 1, Box 1). This implies that the system as a whole operates differently than an analysis of the sum of the parts would suggest. In other words: a risk assessment only at the level of individual banks, or on the individual merits of the various derivatives, is inadequate at the macro level. It is the macro-view, which should provide insight into how the financial innovation of 
packing and selling risks has affected the resilience of the financial system. That insight is essential for assessing which externalities have caused the contagion of the system.

\section{Box 1 The fallacy of composition}

The "fallacy of composition" is the phenomenon that behaviour at the micro level that aims to increase the individual welfare, does not necessarily do so at the macro level, or may even destroy welfare at the macro level. The famous example is a football stadium where all spectators are seated. When the first rows of spectators stand up in order to see more, indeed it gives them a better view. However, the result is that now everyone has to stand up so that the entire stadium has the same view as before, but everyone is now standing instead of be seated so that the overall "welfare" has decreased. The Dutch graphic artist Escher was fascinated by this fallacy of composition in the many variations on the Penrose triangle of his etchings (see figure 1). If one looks only at the vertices - the micro perspective - the picture seems correct , but the overall picture - the macro perspective - is clearly wrong.

The fallacy of composition in the case of risk means that if all individual investors and financial institutions merge risks in packets to yield low-risk high-return investments and sell it to each other, at a macro level the overall risk does not disappear. It is true that the diversification of risk ensures a lower risk premium because of lower expected volatility. However, the buffer which is necessary to the cover the default, remains the same at the macro level. As the global financial system is a closed system, the risks that banks and speculative investors have sold in packages, eventually returns to them in disguise. The fact that the risks of these securitized assets are placed outside the balance of the institutions makes them less visible but does not alter this conclusion. At the level of individual financial institutions everything seemed all right for the supervisors: banks and other lenders complied with their requirements. Their main focus was on monitoring the vertices in the Penrose triangle and therefore it was not sufficiently realized that the system as a whole was not sustainable.

Fourth suspect: winners curse: securitized assets have been bought at too low a price by those undervaluing the risks

This selling of packages of assets - including the "unsafe" subprime mortgages - with different risk profiles made the buyers of the packages loose sight on the size of the underlying risks. The packaging and selling of these assets can be compared to a river with water from different sources. Downstream one does not know anymore from what source the water originates. It is impossible and of no use to verify. In the start-up period of the credit crisis, the packages were bought by those parties, which made the lowest estimates of the risks. In selling and reselling of the packages in the end the risks were considerably underestimated. This resembles the problem of the winner's curse (Box 2). Note that in this interpretation of why risks were underestimated, and hence too high a price was paid for the assets given their true risk profile, cannot be considered irrational or erroneous behaviour. It is simply the outcome of the risk model when uncertainty about the magnitude of the risk exists, even in case of differences in preferences regarding risk. This uncertainty about the risks, coupled with the fact that the "unsafe" assets were repackaged and resold, constitutes another major mechanisms which caused the financial system to break down. However, in the analysis of the credit crisis the heterogeneity in the assessment of the risks, and therefore the problem of the winner's curse has so far obtained little attention. 


\section{Box 2 The winner's curse}

As noted in the main text, a key problem in risk assessment, especially in the case of packages of securitized assets, is the heterogeneity of the assessment. Asset holders do not all make similar assessments, especially when there is incomplete and blurred information about the risks. A similar problem exists in the auction for a construction contract where the contract is awarded to the contractor who bids the lowest price. It is most probable that this "winner" has underestimated the costs and that this will eventually lead to a loss - or, still worse, that the "winner" is unable to fulfill the contract and will go bankrupt. This is called "the winners curse". Nobel Prize winner Vickrey has even formulated a system - the Vickrey auction - to avoid this curse, namely that the contract be awarded to the bidder with the lowest price at the price of the second lowest bidder. More generally, the problem occurs in any system characterized by an auction market where items are sold to the highest bidder. In the case of cascades of sales of risks, which is a characteristic of the markets for collateralized debts and securitized assets the risks are systematically underestimated. It is evident that in such markets the winner's curse has a reinforcing effect and can contribute to the amplification of an initial shock

This section discussed some major causes of the credit crisis and the breakdown of the financial system. These causes may provide a clue on what externalities future regulation of the financial markets should try to internalize. However, in the policy and economic debates of the credit crisis much more causes have been put forward. It seems that knowledge on externalities, and hence on policies that may prevent future systemic failures, are blurred by misconception about the causes of the crisis. The following section discusses these misconceptions.

\section{Misconceptions about causes of the crisis}

\section{High bonuses}

A first misconception is that high bonuses are the major culprits of the crisis and that by restricting bonuses, either through an appeal on morality or through taxation, future systemic crises can be avoided. The misconception here is that not the bonuses but the way the financial sector has made profits poses the real problem.

In itself there is nothing wrong with businesses making profits and rewarding those responsible for the profits with bonuses. There is little protest against the high rewards that clubs and tournament organizers give to athletes who deliver an exceptional performance and hence contribute to full stadiums and collect major television and advertising revenues. Many enjoy these performances which contribute directly to social welfare. The same is true for top artists. Here the relationship between performance and social welfare is direct and clear. The relationship between the performance of a director or board of directors of a large industrial enterprise, the profits of that enterprise and their contribution to welfare is already somewhat more complicated. The question is whether the profits can be attributed to a good business strategy, to inventive and skilled employees or to external factors such as a favorable climate or cyclical situation. But when the profits of such an enterprise contribute to social welfare and are not obtained at the expense of the welfare of others is, there is no reason for politicians or regulators to oppose bonuses to be paid to successful entrepreneurs. 
This also applies to profits of financial institutions in case there exists a similar link between performance and direct contribution to welfare creation. It should be remembered that the traditional function of these institutions is to intermediate between individuals and companies who need money to invest, and individuals and companies who have saved money that they want to be invested. The intermediation is concerned about the alignment of the amounts of money, the time profiles, the rate of returns and the risks. This traditional business of financial institutions obtains its profits from the skills and knowledge to realize these forms of intermediation at the lowest possible costs. The institutions that manage best, make the highest profits while also contributing to social welfare. In this situation there is nothing wrong with payment of bonuses in order to reward specific and scarce skills.

The problem is that the financial sector in recent decades has drifted further and further away from the traditional business. Financial innovations - eg. securitization - and institutional changes - eg. merging of commercial banks and insurance companies make it unclear what the real source of the profits of financial institutions is. Investment banks and private investment funds undertook various activities to profit from mergers and take-overs. Often the intention of these activities was not to create value contributing to social welfare. Profitability in the short term is obtained at the expense of profits in the long term. The recent case of the "help" that Goldman Sachs offered the Greek government to hide huge government deficits, is a good example. It appears that the only purpose of these specific financial innovations is to shift profits from the future to the present, leaving the future generation with an obligation to be productive and inventive, but where the rewards have already been given away. A sign on the wall is that the rates of returns, and especially the growth in size of the financial institutions in the period before the credit crisis have, for many years, been significantly higher than in the real economy (see eg. Knot and Van Hengel, figure 5, this volume). It is unlikely that this is exclusively the result of a continuous increase in efficiency bringing down the costs of financial intermediation.

The result is that it is no longer clear to what extent financial institutions really contribute to welfare, or whether they earn their profits at the expense of the welfare of others. In the latter case the financial institutions do not contribute to an increase of the cake of welfare, but only to a redistribution to their advantage. It does not seem a redistribution which brings more income equality and is therefore warranted from the perspective of social welfare. On the contrary. The most prominent example of this redistribution of welfare is the too high risks banks have taken in selling and buying securitized assets. The banks assumed that a bailout would prevent them to go bankrupt in case of bad luck whereas in case of good luck the profits from speculation were theirs. And that is exactly what happened. That is why, in the previous section, the moral hazard of the bailout is seen as one of the main culprits of the crisis. It implies that losses were passed to society, while the profits were taken by the banks themselves. My favorite one-liner which I found on internet and which really illustrates this argument is that there was "privatization of profits and socialization of losses". In addition, financial products were developed which made convenient use of tax deductions and which brought small profits to the customers but high profits to the banks. This is also detrimental to society because it lowers tax revenues.

Obviously, these ways of obtaining profits by financial institutions can regarded as market failure, and even as rent seeking - the creaming-off of the welfare of others. The 
role of government and regulators is to repair this market failure and to prevent rent seeking. In other words, to ensure that no profits at the expense of others or at the expense of society as a whole be taken. In that sense the same applies for the financial institutions as for a chemical factory which is to keep the environmental clean and should not be allowed to make high profits through excessive pollution. The focus on bonuses is as if the government allows a chemical plant to make huge profits by tolerating polluting activities on the proviso that no high salaries are paid to the directors and staff. The difference between the government regulation of ordinary businesses and the financial world is that in the latter case, it is much less transparent which is the true contribution to social welfare and to what extent the profits are based on stolen wealth of others. For the design of adequate rules for macro-prudential regulation it is essential to unravel the different sources of profits. However, the financial institutions are keen not to be transparent in this respect and try to throw sand in the eyes of the supervisors about the true strategies for obtaining profits.

All in all this shows again that for a good monitoring and regulation of the financial world a clear understanding should be obtained about the market failures that are caused by financial innovations and the way strategic decisions are made in the financial system. Transparency is needed so that it becomes visible where the financial world actually contributes to welfare, and where there is only redistribution and rent seeking. In case of such adequate regulation profits will not be achieved at the expense of others. In that case there is no need to oppose to bonuses, because there will be no asymmetries in the reward system which yield incentives for taking too high risks.

\section{Low interest rates}

The policy of low interest rates that was especially conducted by the Fed under chairman Greenspan, is seen by some as a major cause of the credit crisis, as it urged banks (and also pension funds) to be more keen on additional returns to their assets. There are arguments to consider this a misconception as well. Firstly there should be some nuance with respect to the fact that interest rates were low: it is true for nominal interest rates but not so much with respect to real interest rates as compared to periods when there was a high inflation. More importantly, the financial system should be set up in such a way that it is resistant to the way cyclical macroeconomic policy is conducted. To use a somewhat sorrowful analogy: during the last large earthquake in China many schoolchildren died, not so much because of the shock of the earthquake which of course is true - but because there had been insufficient supervision on constructing schools which were shockproof.

\section{Large deficits and surpluses in the world}

The huge differences between high spending countries- especially the US with large consumer debts and negative savings rates - and countries with huge surpluses is also regarded as a cause of the crisis. It is true that it has resulted in large imbalances of balances of payments in the world. The rich Arab oil producers and China have enormous surpluses and money to invest, whereas the US and some European countries run large deficits and are to borrow money. Obviously exchange rates are no longer sufficiently flexible to make the balances of payment return to equilibrium. These large savings' surpluses and deficits evoked huge world wide flows of capital where investors tried to obtain the highest rates of return. As yet, this does not explain why it 
is to be regarded as a cause of the crisis. As indicated above, it is the very task of banks and other world wide operating financial institutions, to intermediate between capital owners and investors in need for capital. This intermediation should not pose any problem in a global financial system with perfectly working markets and no market failures. In that ideal world large savings surpluses should even be beneficial for the international financial markets as it requires much intermediation activities.

\section{Rating agencies}

A similar argument holds for the rating agencies which are often considered accountable for the crisis. However, with adequate regulation, banks will not be seduced into taking excessive risks due to an overly positive risk assessment. In that case those rating agents would be selected by the banks, which provide the best and unbiased ratings. But it is true that we (still) do not live in such a perfect world and that it would be better for regulators to conduct their own risk assessment

\section{Shareholders}

Short sighted shareholders are also be blamed for causing the crisis. It is true that the prominent focus of the Anglo-Saxon model on shareholders value may have contributed to irresponsible behaviour of the management of banks, but in case there would have been no prospects for a bailout, shareholders would have lost all of their money in case of bankruptcy. Moreover one may question why, in case of adequate regulation, shareholders of financial institutions would react differently than shareholders of companies in the real economic sector. In that sector there is no complaint that shareholders are responsible for a crisis.

\section{Emotions (although there has been herding which can be seen as rational behaviour)}

Another misconception is that untamed emotions and irrational behavior were a major cause of the crisis. References to emotions and irrational behavior do not provide an analysis which is useful for macro regulation. Moreover, it is inconceivable that emotions play a crucial role in a world where we talk about gains or losses at a magnitude of billions dollars or euro's. As professional poker players should not be guided by emotions and even should hide their own emotions as well as possible, the same holds for the players on the financial markets. In both cases, the "players" are to take rapid decisions under conditions of information uncertainty, both about their own opportunities as well as about the position of others. This requires a refined and experienced intuition, but no emotional or irrational behavior. The difference here is, again, that the decisions of players in the international financial markets bring about externalities, whereas that is not the case in the poker game.

\section{Greed, or even the whole capitalistic system}

Those who consider the crisis a prove of the bankruptcy of the capitalistic system, see unbridled greed as causing the crisis. This too is a misconception: greed, or to put it more neutral, the pursuit of self-interest, enhances, according to mainstream economic theory, economic welfare. In the modern market economy, however, it is the task of the government to minimize undesirable greed - that is, greed that harms others. That is the main argument for government regulation, a regulation which in the case of financial 
markets has not properly taken place because, as mentioned before, there is no good analysis of the externalities which are at the root of the crisis.

\section{The bubble}

Some see the current crisis as the bursting of a bubble, which arose because of buoyant lending and overconsumption, as discussed above. In this perspective, the last misconception is that this crisis can be identified with the bursting of previous bubbles. If that were the case, it should by now be known what the best solution is, or it would even have been possible to prevent the crisis. But every bubble is different. The theory of bubbles provides only a case description, and no causal analysis.

\section{Models can teach us about externalities}

In order to obtain more knowledge on the externalities that were responsible for the amplification of the shock in the credit crisis and that should be internalized by new measures of macro-prudential supervision so as to prevent a next implosion of the financial system, a new type of macro models should be developed. Surely the traditional empirical macro-models with a monetary sector, such as the model of the Banca d'Italia (Fazio et al, 1970) and the MORKMON model (Fase, 1981, De Nederlandsche Bank, 1984, Den Butter, 1988), do not suffice. These models consistently explain the items on the balance sheets of the different economic sectors and consequently the money flows (flow of funds) between those balance sheets. However, the mutual dependency of the banks, and hence the shifting of risk, the associated external effects and the extent of contagion remain out of the picture in these models. The new models should also improve on describing the effect of external shocks such as the fall in housing prices as compared to the models which are nowadays used in macro stress tests to simulate the effects of a massive withdrawal of funds from one bank. (see eg. the model in use at the Netherlands Bank, Van den End, 2008).

In the economics profession a lively debate emerged on which types of models would be appropriate to explain the crisis. The debate was triggered by a question of the Queen of England when visiting the London School of Economics in November 2008. The question was why no one - read no economist - had seen the credit crisis coming. The response of the British Academy to that question of Queen Elizabeth contains the following passage:

"But the difficulty was seeing the risk to the system as a whole rather than to any specific financial instrument or loan. Risk calculations were most often confined to slices of financial activity, using some of the best mathematical minds in our country and abroad. But they frequently lost sight of the bigger picture ". (RES Newsletter, Issue 147, October 2009, p. 8).

This confession of the science community in the UK is at the heart of what has been lacking in the models that monetary authorities avail of in order to restrict the risks of a systemic crisis as much as possible. In the Netherlands a topic in the debate was that it was fully understandable that the models did not foresee the crisis as the dominant type of models are general equilibrium models which are by definition unable to describe and foresee major imbalances. However, according to Den Haan (2009) it is a big 
misunderstanding that all of modern macro models assume an equilibrium. By way of example Den Haan refers to a model of his own which shows that a shock may be large enough to cause a financial crisis from which the economy can not recover without government interference (Den Haan, Ramey and Watson, 2003). This is a so-called dynamic stochastic general equilibrium model with a financial sector, where the label of equilibrium model is misleading because the model can describe many rigidities in the Keynesian tradition, so that activist government intervention may prove necessary.

Gautier (2009) adds to this argumentation that the fact that most economists have been underestimated the probability of the risk of a crisis, is not surprising because it is difficult to distinguish bubbles from fundamental developments. The mainstream models based on rational expectations and on the efficient market hypothesis do not suggest that people make no mistakes, but only that they make no systematic mistakes. From that perspective Gautier lists a number of economic models that were developed long before the credit crisis, but that describe more or less the mechanisms that gave rise to the crisis. In the present context of the crisis the model of Kiyotaki and Moore (1997) is perhaps the most relevant. These authors show how a small fall in property prices can have huge effects, if that property is used as collateral for (mortgage) loans. Their model describes a self-reinforcing process, which shows substantial agreement with the actual developments of the US housing market, which were at the root of the crisis.

There are also macro models that describe multiple equilibriums, which may explain the transition, mentioned before, from an equilibrium of mutual trust between traders in the financial markets to an equilibrium of mutual distrust. Here the theoretical analysis of Diamond (1982) uses an interesting metaphor. It describes a tropical island where the only activities are picking coconuts from the trees and laying on the beach. The inhabitants of this island derive utility from eating the coconuts, but there is a taboo on eating your own coconut. Therefore you must find a trading partner that wants to exchange your coconuts with his or hers, so that you will not consume your own coconuts. In this model there is a good equilibrium where everybody climbs in the trees and picks coconuts for trading them, and a bad equilibrium where nobody is picking coconuts and there is no trade. In the bad equilibrium no coconuts are consumed.

However, these existing models do not, or not explicitly describe the external effects which may be of use to a better design of macro-prudential supervision. Furthermore, the models do not explain the "fallacy of composition" with respect to the risk at the macro level as was worded in the response to the British Queen. Yet, before the crisis a number of models was published which did indeed include externalities which could lead to a breakdown of the financial system. Wagner (2009) gives an overview of these models. He makes a distinction between models that include externalities that lie outside the financial system, and models with externalities from inside the system that make the difficulties of individual banks manifest. According to Wagner this literature suggests that the externalities increase in size as more banks become unable to fulfill their obligations, or have almost reached that situation. These models all show how the adequate regulation could prevent market failure. In particular this concerns regulation by means of capital requirements.

Gai et al. (2008) have specified and elaborated a model that, through an externality, can 
simulate a systemic crisis. This model describes the financial intermediation from a general equilibrium approach where the externality occurs in cases of forced sales of assets during a period of stress. This externality creates a self-reinforcing effect on the economy which jumps from an equilibrium with adequate financial intermediation to a bad equilibrium without financial intermediation. According to this model, financial innovations reduce the probability of such a systemic crisis, but when a crisis occurs it is fiercer than before. Today it is rather amusing is that a simulation with a calibrated version of the model showed that a mild recession may take place once every six years but a deep systemic crisis will occur only once in every 200 years (!). Apparently the description of the mechanisms in the financial system by this calibrated version of the model do not yet fully apply to the situation of the credit crisis.

On the other hand the stimulating model by Gallegati et al (2008) is developed with the implosion of the financial system in mind. These authors, including Nobel laureate Stiglitz, show that securitization has led during the good times of rising housing prices to a strong interdependence of financial institutions. In the down-turn of the economic tide, when housing prices began to fall, this interdependence proved through contagion to result in a negative externality, not foreseen by the supervisors. The externality is that the initial shock of falling house prices, which reduced the value of the packages of unsafe mortgages held by banks, evoked a global distrust between the banks on the value of their mutual debts. The model thus shows why the strong interdependence of financial institutions caused an amplification of the initial shock rather than an absorption of the shock due to the risk diversification. In this way the model also provides a lesson on how a different and better supervision may in the future prevent such crises. The remedy is to stop the further entanglement of the financial markets and avoid contagion but permit risk diversification. Decoupling of different parts of the banking system and a greater diversity in the business form part of the solution. In other words, when the domino stones of the financial markets are set further apart, the chance that all of them fall down at the same shock becomes smaller. However, which specific regulatory measures are needed for this, and how the regulation can be effective with minimal cost, is still to be resolved.

In the model of Acharya et al (2009) a negative externality arises as a systemic risk where the getting into trouble of one financial institution has negative implications for other financial institutions. These authors advocate that when fixing the insurance premiums for deposits one should not only take into account the expectations of the various risks of individual institutions but also the expected systemic risk.

The interesting model of Caballero and Simsek (2009) focuses on the mechanisms which were the actual driving forces in the credit crisis. The model distinguishes three externalities. Besides the network externality and the "fire sales" externality, which were already described in other models, Caballero and Simsek add a complexity externality. This externality takes account of the fact that the financial system has become so complex, for example because of cascades of sales of various types of securitized assets, so that the judgment of the risks gets blurred. If the banks are riskaverse the increased uncertainty about the risks in the network leads to a reduction of welfare of the banks. The result is a negative spiral which is sizeable because a problem in the financial world does not only have an effect on the institutions which therefore also get into trouble (the network externality), but also on all other institutions that lose 
sight of the events. This provides a good description of how a lack of trust resulted in a rapid stop of trade in liquid assets between banks. Caballero and Simsek have not yet elaborated which measures of financial regulation their model suggests in order to avoid a systemic crisis, but it can be expected that a model with three externalities offers an extensive scope for policy measures to internalize these externalities.

All in all, this survey of the macro-economic models, which aim to formalize the functioning of the main mechanisms which caused the credit crisis, shows that these models focus on specifying the externalities and market failures that are responsible for the sudden the collapse of the financial system. The first models which give a somewhat realistic picture of the events are now leaving the drawing board. There is still a long way to go before fully fledged empirical models are available for policy analysis. These models should not only give a qualitative but also a quantitative assessment of the different mechanisms and externalities that created the crisis.

\section{The next recession}

Now that the credit crisis has transmitted to the real economic sector and has resulted in the great recession, the question is how this recession will evolve and how and when we can get out of it. Therefore it is tempting to try and compare this recession with previous ones. However, characteristic for recessions is that they all have a different cause. For that reason, Haberler has already in 1937, in its book Prosperity and Depression, collected for the League of Nations a comprehensive list of the various causes and mechanisms responsible for the succession of good and bad economic times (Haberler, 1937). The current recession, with the credit crisis as a prime cause, can thereby be allotted to the class of the purely monetary theories of the cycle. The variability of the cycle makes the economic tides hard to predict. As a result, it is also difficult to conduct an appropriate cyclical policy. When all cyclical fluctuations would be similar and lookalikes, economists should by now be successful in dampening these fluctuations as much as possible. Ideally, there would be no recessions anymore.

\section{Uncertainty}

Uncertainty is the major problem for the policy response to the next cyclical fluctuation. Economists have learnt to deal with certain types of uncertainty. This is the case when economic time series data show some regular and recurrent patterns so that they can be described by stochastic processes. Then the parameters of these processes can be estimated, given the assumptions on the probability distributions of the data. Even in case probability distributions are unknown, there are parameter free methods to be used. And in most cases of risk, the odds are known. However, there are many other and more fundamental types of uncertainty (Van Asselt, 2000). The most far-reaching, and for the analysis of future events most troublesome type is what Wynne (1992) labels 'ignorance'. It is when we do not know what we do not know. (see also Recuerda Girela, this volume, on ignorance and the precautionary principle). In the Netherlands the Scientific Council for Government Policy (WRR) advises the government on long term policy issues, based on scientific information. When I was a member of that council we discussed possible future developments which would impose problems to the government and on which we were 'ignorant'. Among others, space trash and nanorobots were mentioned. On second thought, however, it seemed that there was too 
little information and that is was too uncertain to dedicate a scientifically based study to these subjects. Moreover there is no complete ignorance about space trash and nanorobots.

\section{Solar storm}

We are also not completely ignorant about the next recession. The periodicity of the cyclical movements in the past makes us presume that after the current recession and following upswing, eventually a new recession will come. However, it is uncertain when that will happen and what the cause and nature of it will be. Here we know what we do not know; the cause will be another one than in the past. Perhaps we must revive, in a modern look, an old and somewhat curious economic theory on the cycle, namely Jevons' theory on sunspots. It may be that within a couple of years a solar storm hits the earth with the same intensity of that of 1859 (Mols, 2009). Let us suppose that it happens in 2012 when the Maya calendar ends. Some see that as the end of times or as the beginning of the new times. By the way, in its new solar cycle prediction of May 29th, 2009, NASA now forecasts the peak of the sunspot activity of 'solar cycle 24' for May 2013. So there may be some postponement of the end of times. Moreover, the activity of solar cycle 24 is predicted to be rather mild as compared to other periods of high solar activity. Yet, that may not prevent the new solar storm to be the beginning of a serious recession. The top of the solar cycle in 1859 was also below average. Its intensity was the result of a coincidence of circumstances where the magnetic field of the electrified gas that took off from the sun interfered with the magnetic field of the earth and hence disturbed its protection. Such a geomagnetic storm will cause much damage to the electricity distribution as it will expose many transformers in the system to permanent damage. It will also disturb all kinds of wireless communication. In 1859, the societal impact of the storm was not yet large because the uses of electricity and radio communication were in its infancies. In 2012 or 2013 it is very different. Nowadays distribution networks for electricity are much interconnected so that the storm may cause a large scale blackout of supply. Moreover, electric power is modern societies' cornerstone technology, the technology on which virtually all other infrastructures and services depend. So, apart from the electricity supply, a severe solar storm will cause an enormous collateral damage. In 2008 a Committee on the Societal and Economic Impacts of Severe Space Weather Events made, under the auspices of the National Research Council in the US, a scenario for a 'severe geomagnetic storm'. The scenario estimates the economic and societal costs to be $\$ 1$ to $\$ 2$ trillion during the first year alone, with recovery times of 4 to 10 years (National Research Council, 2008). So the overall economic and societal costs of the storm may exceed that of the US subprime mortgage crisis.

\section{Avoid contagion}

Another candidate cause for the next recession is when the successor of the Mexican flue will become really dangerous and pandemic. Seemingly, cyclical policy is unable to prevent recessions which such different external causes. Indeed, recessions are inevitable just because the cause of the next recession is unknown. Yet, we can see some similarity in the propagation mechanisms of the initial shocks. In the all three cases, the credit crisis, the solar storm and the pandemic flue, the large worldwide interdependence in the economic system brings about an enormous amplification of the initial shock. In case of the present recession it is the fast growth of the worldwide 
mutual dependence of the banking system which has the subprime mortgage shock amplified towards a systemic crisis. In the previous section we have seen that this 'contagion' acts as an externality in case of a negative shock. Therefore, the deepness of the present recession is mainly the result of the market failure associated with that externality. So, the time has come to think also in a more general context about how the negative externality of contagion can be mitigated in the future. How can the economic system be rearranged so that the far-reaching impact of an inevitable external shock is less strong? How can we avoid that all domino stones in the economic system fall at the same time without doing harm to the enormous welfare gains that globalization has brought us? That knowledge will not prevent a next recession, but will make it less deep.

\section{The future of macro-prudential supervision}

The major argument of this paper is that there has been a blind spot of banking supervision, because it has more and more been oriented at supervision of individual banks. In spite of some early warnings, e.g. by the BIS (see eg. Borio, 2006a, 2006b) macro-prudential supervision has been neglected. As the major, if not only aim of supervision is to internalize externalities and repair market failures, the focus of research that can provide help for macro-prudential supervision in the design of new measures to prevent another systemic crisis, should be directed at finding out about these externalities which were at the root of the crisis. However, even now that various top economists are concerned with formalizing these externalities in new types of macro models, there is still insufficient knowledge on which externalities to internalize. That can also been seen as a valuable excuse for the failure of macro-prudential supervision: nobody, neither from academia nor from the practical profession, has been able to provide supervisors with reliable and credible knowledge on how to prevent a systemic failure. It seems that we still do not know. It is questionable whether more severe capital restrictions and provision of catbonds and coco's, as described by Gelderman (this volume), will solve the whole problem and internalise all externalities. There are similar doubts with respect to the idea of living wills, which provide a recovery and solution to be used when a bank may get into problems (see Avgouleas et al., 2010). These living wills aim to resolve the moral hazard problem from banks that are too big to fail. However, it is not yet clear what kind of externalities are to be internalized by these new instruments and regulations.

Obviously, in future, there should be more restraint in providing too risky credit at too low a price. Yet it seems impossible to return to the 1950's and 1960's when during dr. Holtrop's presidency of the Dutch central bank, unilateral credit restrictions were imposed in case of too high credit creation by the banks. These credit restrictions acted both as a way to avoid inflationary pressure and as an instrument to stabilize the economy (see Fase and Den Butter, 1977). Evidently such restrictions are, in today's perspective, too binding and do not reckon with the diverse positions of banks in the system.

In spite of the fact that knowledge on the true nature of the externalities is still lacking, some preliminary conclusions on the future of supervision can be drawn from the arguments of this paper. These are: 
1. Initial shocks cannot be predicted and prevented: so direct attention to propagation mechanisms

2. Avoid contagion, e.g by the use of financial innovations which only seemingly enhance productivity and macro-economic welfare

3. Make securitization transparent and be based on standards (no over the counter trade) and oblige originators to keep part of their securitized assets (see Fender and Mitchell, 2009); avoid resecuritization.

4. Design the corporate governance structure of financial institutions in such a way that the moral hazard of a bailout is mitigated.

It is obvious that macro-prudential supervision should focus much more than before on internalizing the external effects of today's and tomorrow's activities of the financial sector. In order for such regulation to be efficient, without unnecessary or even counterproductive rules, it is essential to avail of a model based analysis which identifies and quantifies the various mechanisms at work in the financial markets. That analysis will provide insights in the relative importance of the externalities and related risks, and it will yield indicators for supervisors to benchmark target values. It may also show how institutional changes can mitigate the contagion and correlation of risks in the present context of bounded rational behaviour. Such supervision will surely bring about rules and regulations which, on the short run, are binding, both for individual financial institutions as for the sector as a whole. However, on the long run, it will make the system more stable and therefore enhance economic development.

\section{References}

Acharya, V.V., J.A.C. Santos en T. Yorulmazer (2009), Systemic risk and deposit insurance premiums, FRBNY Economic Policy Review, to appear.

Asselt, M. van (2000) Perspectives on uncertainty and risk, the PRIMA approach to decision research, Boston: Kluwer Academic Publishers

Avgouleas, E., Ch. Goodhart and D. Schoenmaker (2010), Living wills as catalyst for action, DSF Policy Paper No. 4.

Borio, C. (2006a), Monetary and fiscal stability: Here to stay?, Journal of Banking and Finance, 30, pp. 3407-3414;

Borio, C. (2006b), The macroprudential approach to regulation and supervision: where do we stand?, Ch. 7 in Erfaringer og Utfordringer, Kredittilsynet 1986-2006, Jubileumsskrift - 20 år som integrert finanstilsyn, Kredittilsynet, pp. 108-120.

Bullard, J., C.J. Neely en D.C. Wheelock (2009), Systemic risk and the financial crisis: a primer, Federal Reserve Bank of St. Louis Review, 91, pp. 403-417.

Butter, F. A. G. den (1988), The DNB econometric model of the Netherlands economy (MORKMON), in W. Driehuis, M.M.G. Fase en H. den Hartog (red.), Challenges for Macroeconomic Modelling, Amsterdam: North-Holland, pp. 405-431.

Caballero, R.J., en A. Simsek (2009), Fire sales in a model of complexity, NBER Working Paper nr. 15479. 
De Nederlandsche Bank (1984), MORKMON, een Kwartaalmodel voor

Macro-economische Beleidsanalyse, Monetaire Monografieën nr. 2, Deventer: De Nederlandsche Bank N.V./Kluwer.

De Nederlandsche Bank (2009), Financiële stabiliteit: overheidssteun aan de financiële sector, DNB kwartaalbericht juni 2009, pp. 22-25.

Diamond, P. A. (1982), Aggregate-demand management in search equilibrium, Journal of Political Economy 90, pp. 881-894.

End, J.W. van den (2008), Liquidity stress-tester: a macro model for stress-testing banks' liquidity risk, DNB Working Paper No. 175, Mei 2008.

Fase, M.M.G. (1981), Financiële activa, rentevorming en monetaire beheersbaarheid; proeve van een monetair kwartaalmodel voor Nederland, in E. den Dunnen, M.M.G. Fase en A Szász (red.), Zoeklicht op Beleid, Leiden/Antwerpen: Stenfert Kroese BV, pp. 43-81.

Fase, M.M.G. and F.A.G. den Butter (1977), The endogeneity of monetary policy in the Netherlands, Cahiers Économiques et Monétaires, 6, Banque de France, pp. 177-204

Fazio, A., G. Caligiuri, F. Cotula en P. Savona (1970), A Model of the Financial sector of the Italian Economy, Paper gepresenteerd op het Second World Congress of the Econometric Society, September 1970, Cambridge, England.

Fender, I, and J. Mitchell (2009), The future of securitisation: how to align incentives?, BIS Quarterly Review, September 2009, pp. 27-43.

Gai, P., S. Kapadia, S. Millard en A. Perez (2008), Financial innovation, macroeconomic stability and systemic crises, Economic Journal, 118, pp. 401-426.

Gallegati, M., B. Greenwald, M.G. Richiardi en J.E. Stiglitz (2008), The asymmetric effects of diffusion processes: risk sharing and contagion, Global Economy Journal, 8, Issue 3, Article 2.

Gautier, P.A., (2009) Crisis niet goed voorspellen is niet hetzelfde als alle realiteitszin verloren hebben, Me Judice, jaargang 2, 4 december 2009.

Haan, W.J den. (2009), Gooi niet alle macro-economische modellen op één hoop, Me Judice, jaargang 2, 21 oktober 2009

Haan, W den., G. Ramey en J. Watson (2003), Liquidity flows and fragility of business enterprises, Journal of Monetary economics, 50, pp. 1215-1241

Haberler, G. (1937) Prosperity and depression; a theoretical analysis of cyclical movement. Geneva: League of Nations

Hinloopen, J. (2007), Een verzekeringsparadox, Economisch Statistische Berichten, 92, pp. 526-527. 
International Monetary Fund (IMF) (2007), Global Financial Stability Report, Issue September 2007, Washington DC

Kiyotaki, N. en J. Moore (1997).Credit cycles, Journal of Political Economy, 105, pp. 211-248.

Lucas, A. (2002), Het risicobegrip vanuit het perspectief van de financiële economie en de kansrekening, in B. Wissink en J. Bouma (red.), Perspectieven op Milieurisico's, WRR Werkdocument W128, pp. 25-66.

Mols, B. (2009) De zon is boos (the sun is angry), Natuurwetenschap \& techniek, 77 (6), 24-33.

National Research Council (2008), Severe space weather events - understanding societal and economic impacts, Workshop Report, Washington DC: National Academies Press.

Wagner, W. (2009), In the Quest of Systemic Externalities: a Review of the Literature, mimeo CentER, European Banking Center, TILEC and Department of Economics, Tilburg .

Wynne, B. (1992), Uncertainty and environmental learning: reconceiving science and policy in the preventive paradigm, Global environmental change, June, 111- 127. 